\title{
The Anaplerotic Phosphoenolpyruvate Carboxylase of the Tricarboxylic Acid Cycle Deficient Acholeplasma laidlawii B-PG9
}

\author{
By JOHN T. MANOLUKAS, ${ }^{1}$ MARSHALL V. WILLIAMS ${ }^{1,2}$ \\ AND J. DENNIS POLLACK ${ }^{1 *}$ \\ ${ }^{1}$ Department of Medical Microbiology and Immunology, and ${ }^{2}$ The Comprehensive Cancer Center, \\ The Ohio State University, Columbus, Ohio 43210, USA
}

(Received 15 July 1988; revised 29 September 1988; accepted 10 October 1988)

\begin{abstract}
Phosphoenolpyruvate carboxylase (EC 4.1.1.31) (PEP-C) was purified approximately 770-fold from the mollicute Acholeplasma laidlawii B-PG9. The partially purified PEP-C required phosphoenolpyruvate (PEP) and $\mathrm{MnCl}_{2}$ at $\mathrm{pH} 7.4$ or $\mathrm{MgCl}_{2}$ at $\mathrm{pH} 8.6$ for optimal activity. The product is oxaloacetate as detected by a malate dehydrogenase indicator system. The $K_{\mathrm{m}_{\mathrm{A}}}$ (PEP variable) was $0.66 \mathrm{mM}$ and the $K_{\mathrm{m}_{\mathrm{B}}}$ (bicarbonate variable) was $1.02 \mathrm{mM}$. At low bicarbonate concentrations ( $0.5 \mathrm{mM})$, PEP-C activity was stimulated approximately $240 \%$ by fructose $1,6-$ bisphosphate. Aspartate was a non-competitive inhibitor of PEP-C activity. The $K_{\mathrm{i}_{\mathrm{A}}}$ (PEP variable) for aspartate was $0.69 \mathrm{mM}$ and the $K_{\mathrm{i}_{\mathrm{B}}}$ (bicarbonate variable) was $0.99 \mathrm{mM}$. Malate, citrate, isocitrate, 2-oxoglutarate, acetyl-CoA, CMP, CDP, GDP, GTP, ADP and ATP had no effect on the PEP-C reaction. The Hill interaction coefficient was $0.98-1 \cdot 11$. The molecular mass by sucrose density gradient analysis was $353 \mathrm{kDa}$; by gel filtration chromatography it was $384 \mathrm{kDa}$. The Stokes radius was about $7 \cdot 4 \mathrm{~nm}$. PEP-C activity and its inhibition by aspartate in Acholeplasma laidlawii B-PG-9 extracts may reflect an involvement of this enzyme in the interdependent regulation of protein, lipid and nucleic acid precursor metabolism of this TCAcycle-deficient and cytochrome-less mollicute.
\end{abstract}

\section{INTRODUCTION}

Phosphoenolpyruvate carboxylase (PEP-C) (EC 4.1.1.31) catalyses the irreversible carboxylation of PEP to oxaloacetate (Ashworth \& Kornberg, 1963). PEP-C is generally considered to be an anaplerotic enzyme, an enzyme with $\mathrm{C}_{4}$-acid-replenishing activity, that is associatec with the tricarboxylic acid (TCA) cycle (Gottschalk, 1986). PEP-C deficient mutants of Escherichia coli (Amarasingham, 1959; Ashworth \& Kornberg, 1963) and Salmonella typhimurium (Theodore \& Englesberg, 1964), with functional 'malic' enzyme and PEP-carboxykinase activities, require additions of TCA cycle intermediates to their culture medium for growth. These studies indicate that in these organisms, PEP-C is the major enzyme activity responsible for replenishment of carbon drained from the TCA cycle for biosynthetic purposes.

Evidence for the presence of PEP-C in any mollicute, specifically, Acholeplasma laidlawii B-PG9, was first obtained by Beaman \& Pollack (1984). Recently, we reported the presence of PEP-C in Acholeplasma morum S2, but not in any species of the related genus Mycoplasma (Manolukas et al., 1988). We found no evidence for a functional TCA cycle in any mollicute, and only detected malate dehydrogenase (MDH) (EC 1.1.1.37) activity in all the Mycoplasma species, but no other TCA cycle enzyme activity. In unpublished studies with Ureaplasma urealyticum T960(CX8) we also failed to detect PEP-C activity and found the identical anaplerotic-TCA-cycle-deficient metabolic pattern we have described for all Mycoplasma species (Manolukas et al., 1988).

Abbreviations: PEP-C, phosphoenolpyruvate carboxylase; PEP, phosphoenolpyruvate; TCA, tricarboxylic acid; MDH, malate dehydrogenase. 
In order to study the properties of PEP-C in an organism without a functional TCA cycle (Manolukas et al., 1988), nor cytochrome pigments (Pollack et al., 1981), we have purified the enzyme present in Acholeplasma laidlawii B-PG9. To determine the role of this enzyme in mollicute metabolism, the sensitivity of the purified enzyme to various activators and inhibitors of PEP-C in other organisms was tested.

\section{METHODS}

Materials. Phosphoenolpyruvate (PEP) was from Sigma. Matrix Gel Green A was from Amicon. DEAE Sephacel, Sephadex (superfine) G-200 particle size 10-40 $\mu \mathrm{m}$ and Phenyl-Sepharose CL-6B were from Pharmacia.

Preparation of cell extract. Acholeplasma laidlawii B-PG9 was grown at $37^{\circ} \mathrm{C}$ in modified Edward medium (Beaman \& Pollack, 1981). Cytoplasmic extracts were prepared from washed cells after lysis by explosive decompression in a Parr-Bomb. The lysate was centrifuged at $260000 \mathrm{~g}$ for $1.5 \mathrm{~h}$ at $4{ }^{\circ} \mathrm{C}$ and the supernatant was dialysed overnight in EQ-buffer (20 mM-Tris/ $\mathrm{HCl}, \mathrm{pH} \mathrm{7.4,1} \mathrm{mM-2-mercaptoethanol,} 1 \mathrm{mM}-\mathrm{MgCl}_{2}$ and $20 \%, \mathrm{v} / \mathrm{v}$, glycerol) at $4{ }^{\circ} \mathrm{C}$. The dialysed supernatant (cytoplasmic extract) was the starting material for all assays and purification studies.

Assay for PEP-C. This was a modification of the procedure described by T. E. Smith (1968). The basic reaction mixture (1.0 ml) contained $100 \mathrm{mM}$-HEPES (pH 7.4), $6 \mathrm{mM}-\mathrm{PEP}, 5 \mathrm{mM}-\mathrm{MnCl}_{2}$ (or $5 \mathrm{mM}-\mathrm{MgCl}_{2}$ as indicated) and as an indicator system 0.1 U MDH and 0.15 mM-NADH and various amounts of enzyme (0.02-910 $\mu \mathrm{g}$ protein). The effects of $\mathrm{pH}$, metal ions, inhibitors and activators on $0.13 \mu \mathrm{g}$ of partially purified PEP-C protein was determined. Reactions were started with the addition of $10 \mathrm{mM}$, or $0.5 \mathrm{mM}$, sodium bicarbonate. The specific activity values were determined from the change in absorbance in time, measured spectrophotometrically at $340 \mathrm{~nm}$ at $22-25^{\circ} \mathrm{C}$. A unit of PEP-C activity was the amount of enzyme which produced $1 \mu$ mol oxaloacetate $\min ^{-1}$ from PEP at $22-25^{\circ} \mathrm{C}$.

Purification of A. laidlawii $B$-PG 9 PEP-C. All purification procedures were done at $4^{\circ} \mathrm{C}$. The cytoplasmic extract was loaded onto a Green A column $\left(2.5 \times 20 \mathrm{~cm}\right.$, flow rate $\left.0.5 \mathrm{ml} \mathrm{min}^{-1}\right)$ equilibrated in EQ-buffer. The column was washed with EQ-buffer and PEP-C activity was eluted from the column by the addition of a $6 \mathrm{mM}$ solution of PEP in EQ-buffer. After dialysis against EQ-buffer, fractions containing PEP activity were pooled and ammonium sulphate was added to a final concentration of $3 \mathrm{M}$. The mixture was centrifuged at $30000 \mathrm{~g}$ for $30 \mathrm{~min}$ and the precipitate, which contained PEP-C activity, was dissolved in about $1.5 \mathrm{ml}$ EQ-buffer with $0.8 \mathrm{M}$ ammonium sulphate (EQA-buffer). The solution was applied to a Phenyl-Sepharose column $(1.5 \times 28 \mathrm{~cm}$, flow rate $0.5 \mathrm{ml} \mathrm{min}^{-1}$ ) equilibrated in EQA-buffer. The column was eluted with EQA-buffer $+10 \mathrm{~mm}$-aspartate following the technique of Izui et al. (1982). Fractions $(1 \mathrm{ml})$ were collected, dialysed against EQ-buffer and assayed for activity. The pooled active fractions were chromatographed on a DEAE-Sephacel column $\left(2.5 \times 30 \mathrm{~cm}\right.$, flow rate $\left.0.5 \mathrm{ml} \mathrm{min}^{-1}\right)$ equilibrated in EQ-buffer. PEP-C activity was eluted with a linear gradient of increasing concentration of $\mathrm{KCl}$ in EQ-buffer. The PEP-C activity eluted at $0.41 \mathrm{M}-\mathrm{KCl}$. Fractions containing PEP-C activity were dialysed against EQ-buffer.

The dialysed active fractions were pooled and $2.0 \mathrm{ml}$ were chromatographed on a Sephadex G-200 gel filtration column $\left(2.0 \times 53 \mathrm{~cm}\right.$, flow rate $\left.0.2 \mathrm{ml} \mathrm{min}{ }^{-1}\right)$ equilibrated in EQ-buffer. PEP-C activity was eluted with EQbuffer. Active fractions were pooled and this sample was used for further studies.

Optimal pH determination. $\mathrm{pH}$ optimum was determined from $3 \cdot 4$ to $10 \cdot 3$, using different buffers in the PEP-C assay (final concentration $50 \mathrm{mM}$ ): dimethylglutaric acid/ $\mathrm{NaOH}, \mathrm{pH} 3.4$ to 7.6 ; imidazoleacetic acid, $\mathrm{pH} 7.1$ to 7.8; Tris/acetic acid, $\mathrm{pH} 7.4$ to 8.9 ; and glycine/ $\mathrm{NaOH}, \mathrm{pH} 8.6$ to 10.3 .

Determination of divalent cation requirement. To determine the divalent cation requirement and concentration yielding the maximum specific activity of PEP-C, $\mathrm{MgCl}_{2}$ or $\mathrm{MnCl}_{2}$ were added individually or together to the PEP-C reaction mixture at final concentrations ranging from 0 to $10 \mathrm{mM}$. Divalent cation requirements were examined over the range of $\mathrm{pH}$ values listed above.

Inhibition and activation studies. Under standard assay conditions for PEP-C, known inhibitors and activators of PEP-C (Maeba \& Sanwall, 1969; T. E. Smith 1970; Morse et al., 1974; Cox \& Baugh, 1976) were tested. Aspartate, malate, citrate, isocitrate, 2-oxoglutarate, succinate and fumarate were tested at $10 \mathrm{mM}$, ATP, ADP, GTP, GDP, CDP and CMP at $4 \mathrm{mM}$, fructose 1,6-bisphosphate at $8 \mathrm{mM}$ and acetyl-CoA at $0.1 \mathrm{~mm}$. These studies were done at both $0.5 \mathrm{~mm}$ - and $10 \mathrm{~mm}$-bicarbonate levels.

Molecular mass determination. The molecular mass of the PEP-C was determined by sedimentation analysis and by gel filtration chromatography. Sucrose gradient centrifugation was done in a linear $(5-20 \%$, w/v) sucrose gradient ( $50 \mathrm{~mm}$-Tris/HCl, pH 7.5, $2 \mathrm{~mm}$-2-mercaptoethanol, $100 \mathrm{mM}-\mathrm{NaCl}, 2 \mathrm{mM}-\mathrm{MgCl}_{2}$ ) at 35000 r.p.m for $15 \mathrm{~h}$ in a SW41 Ti rotor (Beckman) at $4^{\circ} \mathrm{C}$. Approximately $100 \mu \mathrm{g}$ protein was loaded onto each gradient. After centrifugation, fractions $(0.5 \mathrm{ml})$ were collected and assayed for protein and PEP-C activity. The protein standards (Sigma) used were PEP-C (402 kDa), $\alpha$-amylase (200 kDa), alcohol dehydrogenase (141 kDa), creatine phosphokinase $(81 \mathrm{kDa})$ and bovine serum albumin $(\mathrm{BSA})(67 \mathrm{kDa})$. The sedimentation coefficient was estimated 
by the method of Martin \& Ames (1961). Gel filtration chromatography was done using a Sephadex G-200 column $(2.0 \times 53 \mathrm{~cm})$ equilibrated in EQ-buffer. Partially purified enzyme $(100 \mu \mathrm{g})$ was added to the column and eluted with EQ-buffer. Fractions $(2.5 \mathrm{ml})$ were collected and assayed for PEP-C activity and protein. The Stokes radius was determined by the procedure of Siegel \& Monty (1966).

Gel electrophoresis. Polyacrylamide tube gel electrophoresis was done on $50 \mu \mathrm{g}$ protein of the partially purified PEP-C as described previously (Williams \& Pollack, 1984). After electrophoresis, the gels were either stained with Coomassie blue or cut into $3 \mathrm{~mm}$ slices for assaying PEP-C activity. Each slice was immersed in $1 \mathrm{ml}$ of the standard reaction mixture without the indicator system (0.1 U MDH and $0.15 \mathrm{mM}-\mathrm{NADH})$ and incubated at $25^{\circ} \mathrm{C}$ for $10 \mathrm{~h}$. The indicator system was then added and the reaction monitored at $A_{340} \mathrm{~nm}$.

Kinetic analysis. To calculate $K_{\mathrm{m}}$ values, initial reaction velocities were determined at various concentrations of bicarbonate $(0 \cdot 2-2 \mathrm{mM})$ and fixed PEP concentrations $\left(0 \cdot 5,5,10 \mathrm{mM} ; K_{\mathrm{m}_{\mathrm{A}}}\right.$ for PEP), and at various concentrations of PEP (0.2-3 mM) and fixed bicarbonate concentrations $\left(0 \cdot 5,2,4 \mathrm{mM} ; K_{\mathrm{m}_{B}}\right.$ for bicarbonate). Besides PEP and bicarbonate, the reaction mixtures also contained in $1 \mathrm{ml} 0 \cdot 1 \mathrm{U}$ partially purified PEP-C, $0 \cdot 1 \mathrm{U}$ MDH, $0 \cdot 15 \mathrm{mM}-$ $\mathrm{NADH}, 5 \mathrm{~mm}-\mathrm{MnCl}_{2}$, and $50 \mathrm{~mm}$-HEPES.

The inhibition constants for aspartate were determined in $1.0 \mathrm{ml}$ with $0.1 \mathrm{IU}$ partially purified PEP-C, at a fixed concentration of PEP $(0.66 \mathrm{mM})$ and varying bicarbonate concentrations $\left(0.1-1 \mathrm{mM} ; K_{\mathrm{i}_{\mathrm{A}}}\right.$ for aspartate), and at a fixed concentration of bicarbonate $(1 \mathrm{mM})$ and varying PEP concentrations $\left(0 \cdot 1-1 \mathrm{mM} ; K_{\mathrm{i}_{\mathrm{B}}}\right.$ for aspartate), using three different aspartate concentrations $(2,4,8 \mathrm{mM})$. The Hill coefficient $(n)$ was determined as described by Suelter (1985).

Other assays. Protein concentrations were determined by their direct relationship to the absorbance difference $A_{215}$ minus $A_{225}$ (Waddell, 1956) using BSA as the standard.

Pyrophosphate formation was assayed using the $\mathrm{PP}_{\mathrm{i}}$ assay reagent kit (Sigma).

\section{RESULTS}

Purification of $A$. laidlawii $B-P G 9$ PEP-C. The results of the purification of PEP-C from A. laidlawii B-PG9 are summarized in Table 1. Purification of $600-700$-fold was routinely achieved. There was no loss of activity after storage at $-20^{\circ} \mathrm{C}$ for 2 months. The enzyme activity was higher after passage through the Green A dye affinity column, presumably due to the removal of an inactivator of the enzyme or to a competing enzyme activity. Therefore, enzyme recovery was calculated relative either to the cytoplasmic fraction or to the eluate of the Green A column. Using the eluate from the Green A column, the average recovery was $15 \%$.

Electrophoretic analysis of the enzyme preparation following Sephadex G-200 chromatography demonstrated that the enzyme preparation contained two protein species. Based upon the ability to detect bands containing $0.8 \mu \mathrm{g}$ protein, we calculated that these two proteins composed at least $99 \%$ of the protein in the preparation. Compared to a series of BSA standards, we estimate that the minor band was about $2 \%$ of the total protein. Following electrophoresis, all PEP-C activity was associated with the major protein species $\left(R_{F} 0 \cdot 36\right)$.

$p H$ and divalent cation requirements. We found that either $\mathrm{MgCl}_{2}$ or $\mathrm{MnCl}_{2}$ was required for enzyme activity. $\mathrm{CaCl}_{2}, \mathrm{CoCl}_{2}$ and $\mathrm{ZnCl}_{2}$ could not replace $\mathrm{MgCl}_{2}$ or $\mathrm{MnCl}_{2}$. Maximal enzyme activity occurred at $5 \mathrm{mM}$ at $\mathrm{pH} 7.5$ with $\mathrm{MnCl}_{2}$ and at $5 \mathrm{mM}$ at pH 8.5 with $\mathrm{MgCl}_{2}$. At $\mathrm{pH} 7.9$, the activity of the enzyme with either chloride was approximately equal. At $\mathrm{pH} 7.9$ the maximal

\section{Table 1. Purification of PEP-C activity from A. laidlawii $B-P G 9$}

Data shown are representative. The average purification was $770 \pm 71(n=3)$.

$\begin{array}{cccccccc}\begin{array}{c}\text { Purification } \\ \text { step }\end{array} & \begin{array}{c}\text { Total volume } \\ \text { (ml) }\end{array} & \begin{array}{c}\text { Total } \\ \text { activity } \\ (\mathrm{U})\end{array} & \begin{array}{c}\text { Protein } \\ \left(\mathrm{mg} \mathrm{ml}^{-1}\right)\end{array} & \begin{array}{c}\text { Specific } \\ \text { activity* }\end{array} & \begin{array}{c}\text { Recovery (\%) compared } \\ \text { Cytoplasmic } \\ \text { extract }\end{array} & \text { Green A } & \begin{array}{c}\text { Purification } \\ \text { (fold) }\end{array} \\ \text { ytoplasmic extract } & 40.5 & 108.26 & 2.97 & 0.9 & 100 & & 1 \\ \text { reen dye A } & 24.5 & 434.58 & 0.49 & 36.2 & 401 & 100 & 40 \\ \text { Phenyl-Sepharose } & 12.0 & 192.84 & 0.05 & 321.4 & 178 & 44 & 357 \\ \text { EEAE-Sephacel } & 3.0 & 104.79 & 0.09 & 388.1 & 97 & 24 & 431 \\ \text { Sephadex G-200 } & 7.4 & 65.62 & 0.02 & 591.2 & 61 & 15 & 657\end{array}$

* Expressed in $\mu \mathrm{mol}$ product synthesized $\mathrm{min}^{-1}$ (mg protein) ${ }^{-1}$ in standard assay. 
activity was detected at $5 \mathrm{mM}$ of either chloride or a combination of both to a total concentration of $5 \mathrm{mM}$.

Inhibitors and activators. Using three different batches of partially purified PEP-C, we found that aspartate $(10 \mathrm{mM})$ at a concentration of either 0.5 or $10 \mathrm{mM}$-bicarbonate inhibited the PEP-C reaction to $85-86 \%$ of the control value. Neither malate, citrate, isocitrate, 2-oxoglutarate, succinate nor ATP inhibited PEP-C activity, i.e. activity was within $2 \%$ of that found in control reactions lacking inhibitor. In parallel experiments we similarly tested known activators of PEP-C. Fructose 1,6-bisphosphate at $0.5 \mathrm{mM}$-bicarbonate stimulated the PEP-C reaction to $236-239 \%$ of the control value and at $10 \mathrm{~mm}$-bicarbonate, $2-4 \%$. At $0.5 \mathrm{~mm}$ - or $10 \mathrm{~mm}$ bicarbonate, none of ADP, acetyl-CoA, CDP, CMP, GDP and GTP had any detectable effect on PEP-C activity, i.e. activity was within $2 \%$ of that found in control reactions lacking activator.

Molecular mass determination. In sucrose density gradient studies, an approximate molecular mass of $353 \mathrm{kDa}$ was determined for the partially purified PEP-C from $A$. laidlawii B-PG9. The sedimentation coefficient of this material was approximately $10.8 \mathrm{~S}$. The molecular mass of partially purified PEP-C from $A$. laidlawii B-PG9 was also determined by gel filtration chromatography. The molecular mass was determined by comparing the partition coefficient $\left(K_{\mathrm{av}}\right)$ of the PEP-C from $A$. laidlawii B-PG9 to standards and was calculated to be about $384 \mathrm{kDa}$. The Stokes radius was about $7 \cdot 4 \mathrm{~nm}$.

Kinetic analysis. When the bicarbonate concentration was fixed and the PEP concentration was varied, a $K_{\mathrm{m}_{\mathrm{A}}}$ of $0.66 \mathrm{mM}$ could be calculated. In the presence of aspartate the $K_{\mathrm{i}_{\mathrm{A}}}$ was $0.69 \mathrm{mM}$, which is essentially the same value. However, the maximum velocites for these reactions were different: $V_{\max _{\mathrm{A}}} 1.06 \mu \mathrm{mol} \mathrm{min}^{-1}$ and $V_{\max _{\mathrm{A}}} 0.86 \mu \mathrm{mol} \mathrm{min} \mathrm{m}^{-1}$, respectively. When the PEP concentration was fixed and the bicarbonate concentration was varied a $K_{\mathrm{m}_{\mathrm{B}}}$ of $1.02 \mathrm{mM}$ could be calculated. In the presence of aspartate, the $K_{\mathrm{i}_{\mathrm{B}}}$ was $0.99 \mathrm{mM}$, again essentially the same values. The maximum velocities for these reactions were again different: $V_{\max _{B}}$ $1.13 \mu \mathrm{mol} \mathrm{min}^{-1}$ and $V_{\max _{\mathrm{B}}} 0.54 \mu \mathrm{mol} \mathrm{min}^{-1}$, respectively. This pattern is compatible with the interpretation that aspartate is a non-competitive inhibitor of the PEP-C reaction irrespective of which reactant concentration is varied. The Hill interaction coefficient was calculated to be $0.98-1 \cdot 11$.

\section{DISCUSSION}

PEP carboxylase is regulated by a variety of modulators (Scrutton, 1978). As in Neisseria gonorrhoeae (Cox \& Baugh, 1976), the PEP-C from Acholeplasma laidlawii B-PG9 is activated by fructose 1,6-bisphosphate at low ( $0.5 \mathrm{mM})$ bicarbonate levels, but not at higher (10 mM) levels. Fructose 1,6-bisphosphate is an allosteric activator of the NAD-dependent L(+)-lactatespecific lactic dehydrogenase of $A$. laidlawii (Neimark \& Lemcke, 1972), and is also the product of the rate-limiting step of glycolysis in this organism which is mediated by a pyrophosphatedependent phosphofructokinase (Pollack \& Williams, 1986). Accumulation of fructose 1,6bisphosphate in intact and metabolically active cells of Mycoplasma gallisepticum has been demonstrated (Egan et al., 1986). Unlike most other PEP-C, our samples were not stimulated by acetyl-CoA (Scrutton, 1978). Other known activators, CDP, CMP and dCTP of prokaryotic PEP-C were tested but they had no effect on the PEP-C activity from $A$. laidlawii B-PG9.

The PEP-C from $A$. laidlawii B-PG9 is non-competitively inhibited by aspartate as has been observed with the enzyme from other prokaryotes (Scrutton, 1978). Therefore, accumulation of aspartate, either by increased transamination of oxaloacetate (Manolukas et al., 1988) or its reduced use in the synthesis of AMP from IMP (Tryon \& Pollack, 1985) or reduced consumption in other reactions, such as protein synthesis, might inhibit PEP-C activity. Inhibition of $\boldsymbol{A}$. laidlawii PEP-C by aspartate might thus cause an increased rate of conversion of PEP to pyruvate and ATP, the pyruvate then being converted to acetyl-CoA (Constantopoulos \& McGarrity, 1987) and lipids (Smith \& Henrikson, 1965). Regulation of PEP-C activity by aspartate may thus be effective in modulating protein, lipid and nucleic acid precursor metabolism in A. laidlawii B-PG9. 
Other known inhibitors of PEP-C (citrate, isocitrate, 2-oxoglutarate, succinate, fumarate and ATP) were tested, but in our assays these inhibitors had no effect on the activity of partially purified PEP-C of A. laidlawii B-PG9. It is interesting that TCA-cycle components which are known inhibitors of PEP-C activity isolated from prokaryotes with a functional TCA cycle have no effect on the PEP-C activity isolated from a prokaryote which apparently has no functional TCA cycle (Manolukas et al., 1988).

The molecular masses for native PEP-C range from $560 \mathrm{kDa}$ in Coccochloris peniocystis (Owttrim \& Colman, 1986) to a relatively low $105 \mathrm{kDa}$ in Bryophyllum fedtschenkoi (Jones et al., 1978). Wolpert \& Ernst-Fonberg (1975) reported a multienzyme complex of PEP-C, malate dehydrogenase and acetyl-CoA carboxylase of about $360 \mathrm{kDa}$. They separated the PEP-C and determined that it was $183 \mathrm{kDa}$, and was stimulated by either ATP or acetyl-CoA. Our PEP-C of $353-384 \mathrm{kDa}$ has no malate dehydrogenase activity and is not stimulated by either ATP or acetyl-CoA.

Millay et al. (1978) reported that Pseudomonas MA, grown on methylamine as the sole carbon source, produces a tetrameric PEP-C of about $12 \mathrm{~S}$ that is converted by NADH to a more active dimeric form of about $9 \mathrm{~S}$. This NADH-activated conversion is inhibited by ADP. Although ADP has no detectable effect in our experiments, we cannot exclude the possibility that this conversion takes place, because NADH is present in our assay system. Millay \& Hersh (1976) proposed that the flow of carbon into energy-producing pathways is affected by the response of PEP-C to the energy state of the organism, the energy state being reflected by the level of cellular NADH. The availability of NADH at the same PEP-pyruvate locus is obviously also modulating the reduction of pyruvate to lactate, a major end-product of glucose metabolism in fermentative Mollicutes like $A$. laidlawii (P. F. Smith, 1971).

Our calculation of $7.4 \mathrm{~nm}$ for the Stokes radius of $A$. laidlawii PEP-C is close to the value of $7.52 \mathrm{~nm}$ reported for the PEP-C of E. coli (T. E. Smith, 1971).

Our in vitro studies suggest that PEP-C activity may serve $A$. laidlawii B-PG9 by shunting glycolytically derived PEP away from pyruvate, acetyl-CoA and lactate and lipid formation towards amino acids and nucleic acids. This may occur during periods when cellular ATP is not limiting, since by circumventing the synthesis of pyruvate from PEP by pyruvate kinase the concomitant synthesis of ATP may not occur. These data also suggest that fructose 1,6bisphosphate, NADH and aspartate by affecting pyruvate and PEP utilization have an important role in regulating metabolism in $A$. laidlawii.

\section{REFERENCES}

AMARasingham, C. R. (1959). The relative roles of malic enzyme and oxaloacetic acid carboxylase in acetate oxidation. Federation Proceedings 18, 181.

AshWORTH, J. M. \& KorNBerg, H. L. (1963). Fine control of the glyoxylate cycle by allosteric inhibition of isocitrate lyase. Biochimica et biophysica acta 73, 519-522.

Beaman, K. D. \& Pollack, J. D. (1981). Adenylate energy charge in Acholeplasma laidlawii. Journal of Bacteriology 146, 1055-1058.

Beaman, K. D. \& Pollack, J. D. (1984). Enzymatic assimilation of ${ }^{14} \mathrm{C}$ from $\mathrm{NaH}^{14} \mathrm{CO}_{3}$ by extracts of Acholeplasma laidlawii B-PG9. Yale Journal of Biology and Medicine 57, 897.

Constantopoulos, G. \& McGarrity, G. J. (1987). Activities of oxidative enzymes in mycoplasmas. Journal of Bacteriology 169, 2012-2016.

Cox, D. L. \& Baugh, C. L. (1976). Carboxylation of phosphoenolpyruvate by extracts of Neisseria gonorrhoeae. Journal of Bacteriology 129, 202-206.

EgaN, W., BARILE, M. \& RotTEM, S. (1986). ${ }^{31}$ P-NMR studies of Mycoplasma gallisepticum cells using a continuous perfusion technique. FEBS Letters 204, 373-376.
GotTschalK, G. (1986). Bacterial Metabolism. New York: Springer Verlag.

IzUI, K., FujtTa, N. \& Katsuki, H. (1982). Phosphoenolpyruvate carboxylase of Escherichia coli. Hydrophobic chromatography using specific elution with allosteric inhibitor. Journal of Biochemistry 92, 423432.

Jones, R., Wilkins, M. B., Coggins, J. R., Fewson, C. A. \& Malcolm, A. D. (1978). Phosphoenolpyruvate carboxylase from the crassulacean plant Bryophyllum fedtschenkoi Hamet et Perier. Purification, molecular and kinetic properties. Biochemical Journal 175, 391-406.

Maeba, P. \& Sanwal, B. D. (1969). Phosphoenolpyruvate carboxylase of Salmonella. Some allosteric properties. Journal of Biological Chemistry 244, 25492557.

Manolukas, J. T., Barile, M. F., Chandler, D. K. F. \& Pollack, J. D. (1988). Presence of anaplerotic reactions and transamination, and the absence of the tricarboxylic acid cycle in Mollicutes. Journal of General Microbiology 134, 791-800.

MARTIN, R. G. \& AmEs, B. N. (1961). A method for determining the sedimentation behavior of 
enzymes: application to protein mixtures. Journal of Biological Chemistry 236, 1372-1379.

Millay, R. H., JR \& Hersh, L. B. (1976). The reduced nicotinamide adenine nucleotide-activated phosphoenolpyruvate carboxylase from Pseudomonas MA. Correlation of allosteric properties with changes in the sedimentation behavior. Journal of Biological Chemistry 251, 2754-2760.

Millay, R. H., JR, Schilling, H. \& Hersh, L. B. (1978). The reduced nicotinamide adenine nucleotideactivated phosphoenolpyruvate carboxylase from Pseudomonas MA. Further studies on regulatory properties. Journal of Biological Chemistry 253, 1371-1377.

Morse, S. A., Stein, S. \& Hines, J. (1974). Glucose metabolism in Neisseria gonorrhoeae. Journal of Bacteriology 120, 702-714.

Neimark, H. C. \& Lemcke, R. (1972). Occurrence and properties of lactic dehydrogenases of fermentative mycoplasmas. Journal of Bacteriology 111, 633-640.

Owtrrim, G. W. \& Colman, B. (1986). Purification and characterization of phosphoenolpyruvate carboxylase from a cyanobacterium. Journal of Bacteriology 168, 207-212.

Pollack, J. D. \& Williams, M. V. (1986). PPdependent phosphofructotransferase (phosphofructokinase) activity in the Mollicutes (mycoplasma) Acholeplasma laidlawii. Journal of Bacteriology 165, 53-60.

Pollack, J. D., Merola, A. J., Platz, J. \& Booth, R. L., II (1981). Respiration associated components of Mollicutes. Journal of Bacteriology 146, 907-913.

SCRUTTON, M. C. (1978). Fine control of the conversion of pyruvate (phosphoenolpyruvate) to oxaloacetate in various species. FEBS Letters 89, 1-9.

Siegel, L. M. \& MoNTY, K. J. (1966). Determination of molecular weights and frictional ratios of proteins in impure systems by use of gel filtration and density gradient centrifugation. Application to crude preparation of sulfite and hydroxylamine reductases. Biochimica et biophysica acta 112, 346-362.
SMITH, P. F. (1971). The Biology of the Mycoplasmas. New York: Academic Press.

Smith, P. F. \& Henrikson, C. V. (1965). Comparative biosynthesis of mevalonic acid by Mycoplasma. Journal of Bacteriology 89, 146-153.

SMITH, T. E. (1968). Escherichia coli phosphoenolpyruvate carboxylase: characterization and sedimentation behavior. Archives of Biochemistry and Biophysics 128, 611-622.

SMITH, T. E. (1970). Escherichia coli phosphoenolpyruvate carboxylase: competitive regulation by acetyl coenzyme A and aspartate. Archives of Biochemistry and Biophysics 137, 512-522.

SMITH, T. E. (1971). Escherichia coli phosphoenolpyruvate carboxylase. Physical and chemical properties. Journal of Biological Chemistry 246, 4234-4241.

Suelter, C. H. (1985). Protein-ligand complexes and enzyme kinetics. In Practical Guide to Enzymology, pp. 203-255. New York: Wiley Interscience.

TheOdORE, T. S. \& ENGLesberG, E. (1964). Mutant of Salmonella typhimurium deficient in the carbon fixing enzyme phosphoenolpyruvate carboxylase. Journal of Bacteriology 88, 946-955.

Tryon, V. V. \& PollaCk, J. D. (1985). Distinctions in Mollicutes purine metabolism: pyrophosphatedependent nucleoside kinase and dependence on guanylate salvage. International Journal of Systematic Bacteriology 35, 497-501.

WADDELL, W. J. (1956). A simple ultraviolet spectrophotometric method for the determination of protein. Journal of Laboratory and Clinical Medicine 48, 311-314.

Williams, M. V. \& Pollack, J. D. (1984). Purification and characterization of a dUTPase from Acholeplasma laidlawii B-PG9. Journal of Bacteriology 159, 278-282.

WOLPERT, J. S. \& ERNST-FonberG, M. L. (1975). Dissociation and characterization of enzymes from a multienzyme complex involved in $\mathrm{CO}_{2}$ fixation. Biochemistry 14, 1103-1107. 